\title{
MORPHO-PHYSIOLOGICAL AND BIOCHEMICAL EFFECTS OF PLANT GROWTH REGULATORS ON MEDICAGO X VARIA T. MARTYN
}

\author{
SOSNOWSKI, J.*-JANKOWSKI, K. - TRUBA, M. - MALINOWSKA, E. \\ Department of Grassland and Green Areas Creation, Siedlce University of Natural Sciences \\ and Humanities, Prusa 14 Street, 08-110 Siedlce, Poland \\ (phone: +48-25-643-1318) \\ *Corresponding author \\ e-mail: jacek.sosnowski@uph.edu.pl \\ (Received $4^{\text {th }}$ Jan 2018; accepted $16^{\text {th }}$ Apr 2018)
}

\begin{abstract}
The aim of the experiment was to evaluate the effects of a growth regulator on alfalfa (Medicago $x$ varia $\mathrm{T}$. Martyn). The authors of the experiments had had the regulator patented in Poland. There were following experimental variants with different application times: Control - application of distilled water both during the six-true-leaf stage and during the early-bud stage, $\mathrm{AF}_{1}$ - application of the regulator during the six-true-leaf stage and distilled water during the early-bud stage, $\mathrm{AF}_{2}-$ application of distilled water during the six-true-leaf stage and the regulator during the early-bud stage, $\mathrm{AF}_{1,2}-$ application of the regulator both during the six-true-leaf stage and during the early-bud stage. The results were processed statistically with the analysis of variance, while differences between means were verified with Tukey's test $(p \leq 0.05)$. It was found that the growth regulator increased stomatal width and the length of the stomatal pore in the stomata of the upper epidermis of the leaf blade. The application positively affected the length and mass of shoots, the number of shoots, but also the mass of inflorescence and roots. In the aboveground biomass there was a rise in the content of protein, phosphorus, calcium, potassium, magnesium, and titanium.
\end{abstract}

Keywords: auxin, cytokinin, alfalfa, titanium chelate, stomata, biometrics, phytochemistry

\section{Introduction}

Flow of hormones, organic substances secreted by plants, regulates physiological processes, stimulating, among other things, cell division and plant growth (Kocira et al., 2016; Sosnowski et al., 2016a, b, 2017a, b). Some exogenous plant hormones, like auxin and cytokinin, affect the function and growth of stomata (Dodd, 2003; Saibo et al., 2003). In an experiment with pea plants Gupta et al. (1999) and Pospišilovă (2003) found that synthetic hormones regulate the opening and closing of stomata and, at the same time, the intensity of photosynthesis and transpiration. According to Schroeder et al. (2001) red and blue parts of the light spectrum cause stomatal opening, probably with auxin and cytokinin playing an active role in activating proton pump H+-ATPase. There have not been many publications about the effects of synthetic hormones on the changes in the number of stomata and changes in their sizes or about the relationship between those features.

The relationship between the number of stomata per unit area and gas exchange has been proven in experiments with such plants as soya, strawberry (Klamkowski et al., 2008). It was also hypothesised that stomatal reaction to exogenous hormones might be dependent on hormone concentration (Pospišilovă, 2003). A concentration which is too high causes blocking of stomatal pore opening and hinders gas exchange (Ruclová and Pospišilovă, 2001; Dodd, 2003). One of the features of plant hormones is their ability to interact with other hormones, for example, when synthetic auxin and cytokinin, in 
higher amounts, both stimulate ethylene biosynthesis in plant tissue (Lorteau et al., 2001; Khan et al., 2002). However, many supposed reactions of the plants to those hormones may be simply reactions to a high level of ethylene. Another example of interaction is again that between cytokinin and auxin, with them both stimulating cell division in the cambium and vascular system formation. It results in a more effective transport of photosynthetic products throughout the plant and increases plant resistance to stress (Aldesuquy, 2000).

During the last few years an interest in the effects of chemical compounds having hormone-like properties on plants has been growing. Some of the most important exogenous synthetic auxins are: Indole-3-acetic acid (IAA), Indole-3-butyric acid (IBA), Beta-naphtoxy acetic acid (NOA), 1-Naphthaleneacetic acid (NAA) and 2,4dichlorophenoxyacetic acid (2,4-D). The best known exogenous synthetic cytokinins are: 6-benzylaminopurine (BAP) and kinetin also called N6-furfuryladenines (Scacchi et al., 2009). The prospect of using other bio stimulants, one of which is titanium in the form of mineral compounds diluted in water, is also of growing importance. Titanium application can regulate biochemical processes, increasing and speeding up biomass growth. Moreover, it stimulates pollination, fertilization, fruit and seed formation, and increases resistance to bacterial and fungal diseases (Carvajal and Alcaraz, 1998). Titanium speeds up growth and development of leaves and is a catalyst making it easier for a plant to take up and process nutrients from soil and from foliar sprays more efficiently (Carvajal and Alcaraz, 1998).

The aim of the experiment was to evaluate the effects of a growth regulator on Medicago x varia T. Martyn cv. Kometa. An assumption was that its application would affect vegetative and generative development of selected morphological features, influencing the concentration of biomass minerals, such as $\mathrm{P}, \mathrm{K}, \mathrm{Ca}, \mathrm{Mg}, \mathrm{Mn}, \mathrm{Zn}, \mathrm{Mo}$, $\mathrm{Cu}, \mathrm{Ti}$ and organic compounds, like protein, crude fibre, Neutral Detergent Fibre (NDF), Acid Detergent Fibre (ADF), Acid Detergent Lignin (ADL), cellulose, and hemicellulose. Furthermore, the ratios of macro elements $\mathrm{Ca}: \mathrm{P}$ and $\mathrm{K}:(\mathrm{Ca}+\mathrm{Mg})$ were calculated.

\section{Material and methods}

\section{Design of the experiment}

The experiment was carried out in the plant breeding room of the University of Natural Sciences and Humanities in Siedlce (Poland) in 2014, in controlled conditions with the temperature of $24 \pm 2 / 16 \pm 2{ }^{\circ} \mathrm{C}$, humidity of $40 \%$, high pressure sodium lamps used to insure photoperiod of $16 / 8$ and light intensity at $200 \mu \mathrm{mol} \mathrm{m} \mathrm{m}^{-2} \mathrm{~s}^{-1}$. Medicago $\mathrm{x}$ varia T. Martyn cv. Kometa, the plant to be tested, was grown in pots. The experiment was set out in a randomised design, with a control unit, and was replicated four times. The pots were filled with $5 \mathrm{~kg}$ of soil, which was loamy medium sand taken from the plough layer of the $3 \mathrm{~d}$ class according to the Polish classification system. The main characteristics of the soil were as follows: phosphorus - $0.48 \mathrm{~g} \mathrm{~kg}^{-1} \mathrm{DM}$, magnesium $0.10 \mathrm{~g} \mathrm{~kg}^{-1} \mathrm{DM}$; potassium - $0.13 \mathrm{~g} \mathrm{~kg}^{-1} \mathrm{DM}$, copper - $8.7 \mathrm{mg} \mathrm{kg}^{-1} \mathrm{DM}$, and zinc - 22.3 $\mathrm{mg} \mathrm{kg}{ }^{-1} \mathrm{DM}$; boron - $\left.2.3 \mathrm{mg} \mathrm{kg}{ }^{-1} \mathrm{DM}\right)$, manganese - $191 \mathrm{mg} \mathrm{kg}^{-1} \mathrm{DM}$ and iron - 1570 $\mathrm{mg}^{-1} \mathrm{DM}$. Additionally, soil $\mathrm{pH}$ measured in $\mathrm{KCl}$ was $6.3, \mathrm{~N}-\mathrm{NO}_{3}$ concentration was 1.4 $\mathrm{mg} \mathrm{kg}{ }^{-1} \mathrm{DM}, \mathrm{N}-\mathrm{NH}_{4}$ concentration was $60.9 \mathrm{mg} \mathrm{kg}^{-1} \mathrm{DM}$, and $\mathrm{C}_{\text {org }}$ (organic carbon) concentration was $17.1 \mathrm{~g} \mathrm{~kg}^{-1}$. 
The alfalfa seeds were sown in mid-March at a depth of $2-3 \mathrm{~cm}$ in pots $(\mathrm{h}=300 \mathrm{~mm}$, $\varnothing=200 \mathrm{~mm}$ ). When the seeds germinated, three representative seedlings in each pot were left to grow and to be used in the experiment later. The growth regulator applied and exclusively used for the experiment was given a patent by the Patent Office of the Republic of Poland (P/407/790). The regulator contained synthetic auxin (concentration of $35 \mathrm{mg} \mathrm{dm}^{-3}$ ), cytokinin (concentration of $35 \mathrm{mg} \mathrm{dm}^{-3}$ ) and titanium chelate (concentration of $1 \mathrm{mg} \mathrm{dm}^{-3}$ ). The plants were sprayed until they were thoroughly wet, using $0.20 \mathrm{dm}^{3}$ of fluid per pot $\left(0.067 \mathrm{dm}^{3}\right.$ per plant $)$. The plants were treated twice with different experimental combinations, at the six-true-leaf stage, i.e. during the vegetative stage of Medicago x varia T. Martyn and at the early-bud stage, i.e. during the generative stage of Medicago x varia T. Martyn.

\section{Experimental treatment}

- Control - distilled water application during the sixth-leaf stage and during the early-bud stage,

- $\mathrm{AF}_{1}$ - regulator application during the sixth-leaf stage, distilled water application during the early-bud stage,

- $\mathrm{AF}_{2}$-distilled water application during the sixth-leaf stage, regulator application during the early-bud stage,

- $\mathrm{AF}_{1,2}$ - regulator application during the sixth-leaf stage and during the earlybud stage.

All experimental variants were replicated four times.

\section{Analysis of selected morphological features}

The following measurements were recorded: the number of stomata per $1 \mathrm{~mm}^{2}$ of the upper epidermis of the leaf blade, stomatal length and breadth $(\mu \mathrm{m})$, the length of the stomatal pore $(\mu \mathrm{m})$, stem length $(\mathrm{cm})$, the number of shoots per plant, the number of leaves per shoot, root collar diameter $(\mathrm{mm})$, the total mass of the plant ( $\mathrm{g} \mathrm{DM})$, the total mass of shoots (g DM), the mass of leaves (g DM) the mass of inflorescence (g DM), the mass of roots $(\mathrm{g} \mathrm{DM})$, the mass of the aboveground part together with the mass of roots per plant (g DM).

The biometric measurements were taken after the plants were harvested at the end of flowering. Earlier than that, from the beginning till the end of flowering, each newly bloomed flower was counted. Stomatal parameters were determined with the microscope camera (HDCE Delta Optical). The material to be viewed under the microscope was taken from the central part of upper leaf blade surface, with five leaves of each experimental variant used. The dark-field microscope with a magnification of 400 times was applied. Microscope camera images were sent to the computer and all measurements were taken with microscopic imaging software ScopeImage 9.0.

\section{The methods of chemicals estimation}

The plants were harvested, dried and ground to determine the concentration of the following chemical elements: potassium, calcium, magnesium, phosphorus, manganese, zinc, copper, molybdenum, and titanium. Shoots, leaves, and roots were used to determine titanium concentration, but in the case of potassium, calcium, magnesium, potassium, manganese, zinc, copper, and molybdenum a mixture of shoots and leaves 
was used to analyse concentration of those metals. The mineral analyses were reduplicated three times for each experimental variant. Total concentration of potassium, calcium, magnesium, phosphorus, manganese, zinc, copper, and molybdenum was determined with ICP - AES, after dry mineralization in a muffle furnace at $450{ }^{\circ} \mathrm{C}$. Then, $5 \mathrm{ml}$ of a $50 \%$ solution of $\mathrm{HCl}$ was added to the crucible and evaporated in a sand bath to dissolve carbonates and separate silica. Next, $10 \mathrm{ml}$ of a $10 \%$ solution of $\mathrm{HCl}$ was added and the contents were poured into a $100 \mathrm{ml}$ volumetric flask.

Furthermore, the ratios of macro elements $\mathrm{Ca}: \mathrm{P}$ and $\mathrm{K}:(\mathrm{Ca}+\mathrm{Mg})$ were calculated. Then, the concentration of protein, simple sugars, Neutral Detergent Fibre (NDF), Acid Detergent Fibre (ADF), Acid Detergent Lignin (ADL), cellulose, and hemicellulose was measured $\left(\mathrm{g} \mathrm{kg}^{-1} \mathrm{DM}\right)$. The air-dry matter was shredded and ground, and the obtained material was subjected to chemical analysis to determine protein, simple sugars, and dry matter concentration, the latter by determining moisture content. The method of determination was near infrared spectroscopy (NIRS), using the NIRFlex N-500 spectrometer and ready to use INGOT calibration applications.

The results physiological and biometric parameters, the concentration of chemical elements and chemical compounds in the biomass, were statistically processed, using analysis of variance. Tukey's test was used to determine $\mathrm{HSD}_{0.05}$ for means that were significantly different, and standard error was calculated to find out how the values spread. The Statistica 6 programme was used for all data analysis.

\section{Results and discussion}

The results of the experiment showed that regulator application to alfalfa plants did not affect the number and the length of stomata in the epidermis of the leaf blade (Table 1). However, the regulator increased the breadth of stomata, with the widest ones being in variants sprayed one time at the six-true-leaf stage $(13.7 \mu \mathrm{m})$ and in plants treated twice during the six-real-leaf stage and during the early-bud stage $(13.9 \mu \mathrm{m})$. There was a similar effect in the case of stomatal pore length, where the highest increase, compared to the control, was also in plants treated twice (8.5\%). Additionally, treating plants during their early-bud stage, or, broadly speaking, during their generative stage, did not affect their stomata in any way.

Table 1. The effects on growth regulator applied at different times on parameters of stomata in the upper epidermis of the leaf blade

\begin{tabular}{c|c|c|c|c|c|c|c|c}
\hline \multirow{2}{*}{ Variants } & \multicolumn{2}{|c|}{$\begin{array}{c}\text { Stomatal number } \\
{\left[\mathbf{m m}^{2}\right]}\end{array}$} & \multicolumn{2}{c|}{$\begin{array}{c}\text { Stomatal length } \\
{[\boldsymbol{\mu \mathrm { m } ]}]}\end{array}$} & \multicolumn{2}{c|}{$\begin{array}{c}\text { Stomatal breadth } \\
{[\boldsymbol{\mu \mathrm { m } ]}]}\end{array}$} & \multicolumn{2}{c}{$\begin{array}{c}\text { Stomatal pore length } \\
{[\boldsymbol{\mu \mathrm { m } ]}]}\end{array}$} \\
\cline { 2 - 9 } & $\mathbf{M e a n} \pm \mathbf{S E}$ & $\begin{array}{c}+,- \\
{[\%]}\end{array}$ & Mean $\pm \mathbf{S E}$ & $\begin{array}{c}+,- \\
{[\%]}\end{array}$ & Mean $\pm \mathbf{S E}$ & $\begin{array}{c}+,- \\
{[\%]}\end{array}$ & Mean $\pm \mathbf{S E}$ & $\begin{array}{c}+,- \\
{[\%]}\end{array}$ \\
\hline Control & $73 \pm 10.7$ & - & $25.1 \pm 8.17$ & - & $11.9 \pm 7.11$ & - & $13.0 \pm 5.12$ & - \\
$\mathrm{AF}_{1}$ & $76 \pm 12.4$ & +4.11 & $24.9 \pm 9.15$ & -0.80 & $13.7 \pm 8.51$ & +15.1 & $13.9 \pm 3.52$ & +6.9 \\
$\mathrm{AF}_{2}$ & $73 \pm 14.6$ & 0 & $24.7 \pm 7.67$ & -1.6 & $12.1 \pm 7.26$ & +1.7 & $13.2 \pm 4.41$ & +4.6 \\
$\mathrm{AF}_{1,2}$ & $75 \pm 13.9$ & +2.74 & $25.6 \pm 8.94$ & +2.0 & $13.9 \pm 6.75$ & +16.8 & $14.1 \pm 3.97$ & +8.5 \\
\hline $\mathrm{HSD}_{\mathrm{P}=0.05}$ & n.s. & - & n.s. & - & 1.5 & - & 0.67 & - \\
\hline
\end{tabular}

Mean value \pm standard error $(\mathrm{SE}),+,-[\%]-$ increase, decrease to the control, $\mathrm{A}-$ regulator, $\mathrm{F}_{1}-$ sixthleaf stage, $\mathrm{F}_{2}$ - early-bud stage, n.s. - not significant 
The data in Tables 2 and 3 show that as a result of regulator application there were considerable differences between alfalfa plants it terms of the development of their parts and the growing of their mass. In plants treated twice the shoots, in a statistically significant way, were $27.2 \%$ longer than in control plants.

Table 2. The effects of growth regulator applied at different times on biometry of selected morphological features

\begin{tabular}{|c|c|c|c|c|c|c|c|c|}
\hline \multirow{2}{*}{ Variants } & \multicolumn{2}{|c|}{$\begin{array}{l}\text { Stem length } \\
{[\mathrm{cm}]}\end{array}$} & \multicolumn{2}{|c|}{$\begin{array}{c}\text { Number of shoots } \\
\text { per plant }\end{array}$} & \multicolumn{2}{|c|}{$\begin{array}{c}\text { Number of leaves per } \\
\text { shoot }\end{array}$} & \multicolumn{2}{|c|}{$\begin{array}{c}\text { Root collar diameter } \\
{[\mathrm{mm}]}\end{array}$} \\
\hline & $\operatorname{Mean} \pm \mathrm{SE}$ & $\begin{array}{l}+,- \\
{[\%]}\end{array}$ & $\operatorname{Mean} \pm \mathbf{S E}$ & $\begin{array}{l}+,- \\
{[\%]}\end{array}$ & $\operatorname{Mean} \pm \mathbf{S E}$ & $\begin{array}{l}+,- \\
{[\%]}\end{array}$ & $\operatorname{Mean} \pm \mathbf{S E}$ & $\begin{array}{l}+,- \\
{[\%]}\end{array}$ \\
\hline Control & $42.3 \pm 14.2$ & - & $11.5 \pm 2.7$ & - & $35.0 \pm 9.7$ & - & $3.7 \pm 1.8$ & - \\
\hline $\mathrm{AF}_{1}$ & $44.2 \pm 17.1$ & +4.5 & $11.0 \pm 3.8$ & -4.3 & $34.4 \pm 8.5$ & -1.7 & $4.1 \pm 2.0$ & +10.8 \\
\hline $\mathrm{AF}_{2}$ & $42.4 \pm 15.4$ & +0.4 & $9.90 \pm 4.2$ & -13.9 & $34.2 \pm 6.9$ & -2.3 & $3.9 \pm 1.8$ & +5.4 \\
\hline $\mathrm{AF}_{1,2}$ & $53.8 \pm 13.5$ & +27.2 & $14.0 \pm 6.7$ & +21.7 & $35.1 \pm 7.7$ & +0.3 & $4.3 \pm 1.7$ & +16.2 \\
\hline $\mathrm{HSD}_{\mathrm{P}=0.05}$ & 9.4 & - & 2.7 & - & n.s. & - & n.s. & - \\
\hline
\end{tabular}

Mean value \pm standard error $(\mathrm{SE}),+,-[\%]$ - increase, decrease to the control, A - regulator, $\mathrm{F}_{1}$ - sixthleaf stage, $\mathrm{F}_{2}-$ early-bud stage, n.s. - not significant

There were similar results when it comes to the number of shoots. In pots where plants were treated twice there were $21.7 \%$ more shoots than in control plants treated with distilled water. As a result, the mass of shoots was $25 \%$ higher than the mass in the control. Generally, compared to the control, there was a statistically significant increase in the mass of shoots, inflorescence, and roots, both in plants growing in pots where the regulator was applied during the growing stage $\left(\mathrm{AF}_{1}\right)$ and in plants treated twice $\left(\mathrm{AF}_{1,2}\right)$. However, statistical analysis did not show any increase in the number of leaves per shoot, root collar diameter, or leaf mass per plant.

Table 3. The effects of growth regulator applied at different times on the mass of selected plant parts $(\mathrm{g} D M)$

\begin{tabular}{c|c|c|c|c|c|c|c|c|c|c}
\hline \multirow{2}{*}{ Variants } & \multicolumn{2}{|c|}{ Total } & \multicolumn{2}{c|}{ Shoots } & \multicolumn{2}{c|}{ Plants } & \multicolumn{2}{c}{ Inflorescence } & \multicolumn{2}{c}{ Roots } \\
\cline { 2 - 10 } & Mean \pm SE & $\begin{array}{c}+,- \\
{[\%]}\end{array}$ & Mean \pm SE & $\begin{array}{c}+,- \\
{[\%]}\end{array}$ & Mean \pm SE & $\begin{array}{c}+,- \\
{[\%]}\end{array}$ & Mean \pm SE & $\begin{array}{c}+,- \\
{[\%]}\end{array}$ & Mean \pm SE & $\begin{array}{c}+,- \\
{[\%]}\end{array}$ \\
\hline Control & $32.2 \pm 10.2$ & - & $11.0 \pm 2.8$ & - & $16.0 \pm 4.2$ & - & $1.45 \pm 0.78$ & - & $3.70 \pm 1.8$ & - \\
$\mathrm{AF}_{1}$ & $38.9 \pm 10.7$ & +20 & $15.9 \pm 3.1$ & +44 & $15.9 \pm 3.3$ & -0.6 & $2.18 \pm 1.1$ & +50 & $5.00 \pm 2.0$ & +35 \\
$\mathrm{AF}_{2}$ & $32.1 \pm 9.9$ & -0.3 & $11.4 \pm 2.7$ & +3.6 & $15.8 \pm 3.0$ & -1.3 & $1.38 \pm 0.96$ & -4.8 & $3.50 \pm 1.7$ & -5.4 \\
$\mathrm{AF}_{1,2}$ & $40.4 \pm 11.1$ & +25 & $16.1 \pm 3.8$ & +46 & $16.9 \pm 3.9$ & +5.6 & $2.23 \pm 1.3$ & +53 & $5.15 \pm 2.2$ & +39 \\
\hline $\mathrm{HSD}_{\mathrm{P}=0.05}$ & 6.4 & - & 4.1 & & n.s. & - & 0.61 & - & 0.99 & - \\
\hline
\end{tabular}

Mean value \pm standard error (SE),,$+-[\%]-$ increase, decrease to the control, $\mathrm{A}$ - regulator, $\mathrm{F}_{1}$ - sixthleaf stage, $F_{2}$ - early-bud stage, n.s. - not significant

Application of synthetic growth regulators affects nutrient absorption and, at the same time, regulates accumulation and distribution of nutrients. Additionally, there is dependence between application of such regulators and the content of macro and microelements in the aboveground vegetative parts. In the experiment described here (Tables 4 and 5), in the plants treated with the regulator there was an increase only in 
the content of phosphorus, manganese, and potassium, with the latter having the highest increase. In the pots with plants treated once, during the vegetative stage (variant $\mathrm{AF}_{1}$ ), potassium content, compared to the control, grew by $32 \%$, while for plants treated twice the accumulation of this metal was $28.6 \%$ higher.

Table 4. The effects of growth regulator applied at different times on selected macro elements concentration in the above-grant part of plants $\left[\mathrm{g}^{\mathrm{kg}} \mathrm{g}^{-1} \mathrm{DM}\right]$

\begin{tabular}{c|c|c|c|c|c|c|c|c}
\hline \multirow{2}{*}{ Variants } & \multicolumn{2}{|c|}{ Phosphorus } & \multicolumn{2}{c|}{ Potassium } & \multicolumn{2}{c|}{ Magnesium } & \multicolumn{2}{c}{ Calcium } \\
\cline { 2 - 9 } & Mean \pm SE & $\begin{array}{c}+,- \\
{[\%]}\end{array}$ & Mean \pm SE & $\begin{array}{c}+,- \\
{[\%]}\end{array}$ & Mean \pm SE & $\begin{array}{c}+,- \\
{[\%]}\end{array}$ & Mean \pm SE & $\begin{array}{c}+,- \\
{[\%]}\end{array}$ \\
\hline Control & $2.76 \pm 1.08$ & - & $14.7 \pm 8.17$ & - & $2.79 \pm 0.97$ & - & $13.9 \pm 7.38$ & - \\
$\mathrm{AF}_{1}$ & $3.45 \pm 0.87$ & +25 & $19.4 \pm 9.35$ & +32 & $3.01 \pm 1.1$ & +7.9 & $14.0 \pm 5.54$ & +0.7 \\
$\mathrm{AF}_{2}$ & $2.99 \pm 1.07$ & +8.3 & $16.8 \pm 7.75$ & +14.3 & $2.60 \pm 0.69$ & -6.8 & $14.1 \pm 4.89$ & +1.4 \\
$\mathrm{AF}_{1,2}$ & $3.36 \pm 1.11$ & +21.7 & $18.9 \pm 9.19$ & +28.6 & $2.93 \pm 0.87$ & +5.0 & $14.3 \pm 9.11$ & +2.9 \\
\hline $\mathrm{HSD}_{\mathrm{P}=0.05}$ & 0.31 & - & 1.9 & - & n.s. & & n.s. & - \\
\hline
\end{tabular}

Mean value \pm standard error $(\mathrm{SE}),+,-[\%]-$ increase, decrease to the control, $\mathrm{A}-$ regulator, $\mathrm{F}_{1}-$ sixthleaf stage, $\mathrm{F}_{2}$ - early-bud stage, n.s. - not significant

Table 5. The effects of growth regulator applied at different times on selected microelements concentration in the above ground part [ $\left.\mathrm{mg} \cdot \mathrm{kg}^{-1} \mathrm{DM}\right]$

\begin{tabular}{c|c|c|c|c|c|c|c|c}
\hline \multirow{2}{*}{ Variants } & \multicolumn{2}{|c|}{ Manganese } & \multicolumn{2}{c|}{ Zinc } & \multicolumn{2}{c|}{ Copper } & \multicolumn{2}{c}{ Molybdenum } \\
\cline { 2 - 9 } & Mean \pm SE & $\begin{array}{c}+,- \\
{[\%]}\end{array}$ & Mean \pm SE & $\begin{array}{c}+,- \\
{[\%]}\end{array}$ & Mean \pm SE & $\begin{array}{c}+,- \\
{[\%]}\end{array}$ & Mean \pm SE & $\begin{array}{c}+,- \\
{[\%]}\end{array}$ \\
\hline Control & $45.5 \pm 9.12$ & - & $22.4 \pm 6.17$ & - & $5.83 \pm 0.78$ & - & $0.48 \pm 0.23$ & - \\
$\mathrm{AF}_{1}$ & $57.7 \pm 7.36$ & +26.8 & $28.9 \pm 5.98$ & +29.0 & $5.79 \pm 1.08$ & -0.6 & $0.49 \pm 0.19$ & +2.1 \\
$\mathrm{AF}_{2}$ & $47.8 \pm 8.07$ & +5.05 & $27.5 \pm 7.91$ & +22.8 & $6.06 \pm 0.97$ & -1.3 & $0.51 \pm 0.31$ & +6.3 \\
$\mathrm{AF}_{1,2}$ & $58.1 \pm 6.12$ & +27.7 & $29.0 \pm 6.79$ & +29.5 & $6.04 \pm 1.11$ & +5.6 & $0.47 \pm 0.29$ & -2.1 \\
\hline $\mathrm{HSD}_{\mathrm{P}=0.05}$ & 9.1 & - & n.s. & - & n.s. & - & n.s. & - \\
\hline
\end{tabular}

Mean value \pm standard error $(\mathrm{SE}),+,-[\%]-$ increase, decrease to the control, $\mathrm{A}-$ regulator, $\mathrm{F}_{1}-$ sixthleaf stage, $F_{2}$ - early-bud stage, n.s. - not significant

The application of the regulator once, during the vegetative stage, and twice, during both vegetative and generative stages, increased phosphorus and manganese content by over $20 \%$. Additionally, there was a considerable change in titanium concentration in many parts of plants (Table 6). The highest concentration of titanium was in leaves (from 3.24 to $4.01 \mathrm{mg} \mathrm{kg}^{-1} \mathrm{DM}$ ), with a relatively high concentration in shoots (from 2.01 to $2.89 \mathrm{mg} \mathrm{kg}^{-1} \mathrm{DM}$ ), and the lowest amounts in roots (from 0.99 to $1.67 \mathrm{mg} \mathrm{kg}^{-1}$ $\mathrm{DM})$. Treating plants with the regulator increased the total amount of titanium in biomass, with the highest increase in plants treated twice (variant $\mathrm{AF}_{1,2}$ ). Compared to the control, the content of titanium in shoots increased by $43.8 \%$, in leaves by $23.8 \%$, and in roots by as much as $68.7 \%$. Regulator application during the vegetative stage in the strongest way affected the content of titanium in the biomass of roots, by $54.5 \%$. In turn, treating plants in the generative stage resulted in a slight change in the amount of the above metals in plants only by several percent, and the change was statistically 
insignificant. A higher amount of those chemical elements affected ion ratios between some macro elements (Table 7).

Table 6. The effects of growth regulator applied at different times on titanium concentration in shoots, leaves and roots $\left[\mathrm{mg} \cdot \mathrm{kg}^{-1} \mathrm{DM}\right]$

\begin{tabular}{c|c|c|c|c|c|c}
\hline \multirow{2}{*}{ Variants } & \multicolumn{2}{|c|}{ Shoots } & \multicolumn{2}{c|}{ Leaves } & \multicolumn{2}{c}{ Roots } \\
\cline { 2 - 7 } & Mean \pm SE & $\begin{array}{c}+,- \\
{[\%]}\end{array}$ & Mean \pm SE & $\begin{array}{c}+,- \\
{[\%]}\end{array}$ & Mean \pm SE & $\begin{array}{c}+,- \\
{[\%]}\end{array}$ \\
\hline Control & $2.01 \pm 0.72$ & - & $3.24 \pm 1.35$ & - & $0.99 \pm 0.74$ & - \\
$\mathrm{AF}_{1}$ & $2.65 \pm 0.41$ & +31.8 & $3.82 \pm 0.91$ & +8.64 & $1.53 \pm 0.63$ & +54.5 \\
$\mathrm{AF}_{2}$ & $2.13 \pm 0.81$ & +6.01 & $3.38 \pm 1.21$ & +4.32 & $1.04 \pm 0.95$ & +5.05 \\
$\mathrm{AF}_{1,2}$ & $2.89 \pm 0.53$ & +43.8 & $4.01 \pm 1.12$ & +23.8 & $1.67 \pm 0.81$ & +68.7 \\
\hline $\mathrm{HSD}_{\mathrm{P}=0.05}$ & 0.49 & - & 0.41 & - & 0.32 & - \\
\hline
\end{tabular}

Mean value \pm standard error $(\mathrm{SE}),+,-, \%$ - increase, decrease to the control, A - regulator, $\mathrm{F}_{1}$ - sixthleaf stage, $\mathrm{F}_{2}$ - early-bud stage

Table 7. The effects of growth regulator applied at different times on the ratio of some macroelements to others in the above ground part

\begin{tabular}{c|c|c|c|c}
\hline \multirow{2}{*}{ Variants } & \multicolumn{4}{|c}{ Ratio } \\
\cline { 2 - 5 } & $\begin{array}{c}\text { Ca:P } \\
\text { Mean } \pm \mathbf{S E}\end{array}$ & $\begin{array}{c}+,- \\
{[\%]}\end{array}$ & $\begin{array}{c}\text { K:(Ca + Mg) } \\
\text { Mean } \pm \mathbf{S E}\end{array}$ & $\begin{array}{c}+,- \\
{[\%]}\end{array}$ \\
\hline Control & $5.04 \pm 1.21$ & - & $0.88 \pm 0.71$ & - \\
$\mathrm{AF}_{1}$ & $4.05 \pm 0.93$ & -19.6 & $1.14 \pm 0.84$ & +29.5 \\
$\mathrm{AF}_{2}$ & $4.99 \pm 1.12$ & -1.0 & $1.01 \pm 0.62$ & +14.8 \\
$\mathrm{AF}_{1,2}$ & $3.36 \pm 1.02$ & -33.3 & $1.09 \pm 0.48$ & +23.9 \\
\hline $\mathrm{HSD}_{\mathrm{P}=0.05}$ & 0.61 & - & 0.11 & - \\
\hline
\end{tabular}

Mean value \pm standard error $(\mathrm{SE}),+,-, \%$ - increase, decrease to the control, $\mathrm{A}-$ regulator, $\mathrm{F}_{1}$ - sixthleaf stage, $\mathrm{F}_{2}$ - early-bud stage

The lowest Ca: $\mathrm{P}$ ratio was in plants treated twice (3.36), but when the regulator was applied during the six-real-leaf stage the ratio was 4.05, while in the control it was wider, with the value of 5.04. Application during the generative stage did not affect the ratio of $\mathrm{Ca}$ : $\mathrm{P}$. The ratio of $\mathrm{K}:(\mathrm{Ca}+\mathrm{Mg})$ was in a statistically significant way higher for plants treated with the regulator in all variants of the experiments and ranged from 1.01 to 1.14 .

In the biomass, regulator application affected the amount of organic compounds, like protein, fibre, and structural carbohydrates making up the skeleton of the plant cell wall. The effect of regulator application was dependent on the plant development stage at the time of application (Table 8). When the plants were treated during the six-true-leaf stage, a part of the vegetative stage, the content of protein in the biomass increased by $14.5 \%$, while crude fibre decreased by $7.0 \%$. There was a similar effect in plants treated with the regulator twice (variant $\mathrm{AF}_{1,2}$ ). However, compared to the control, regulator application during the early-bud stage, or generative stage, did not affect in a statistically significant way the content of protein and crude fibre. The regulator influence was particularly noticeable in the changing content of cell wall fractions: 
Neutral Detergent Fibre (NDF), Acid Detergent Fibre (ADF), Acid Detergent Lignin (ADL), cellulose, and hemicellulose (Table 9).

Table 8. The effects of growth regulator applied at different times on total protein and crude fibre concentration in the above-ground parts $\left[\mathrm{g} \mathrm{kg}^{-1} \mathrm{DM}\right]$

\begin{tabular}{c|c|c|c|c}
\hline \multirow{2}{*}{ Variants } & \multicolumn{2}{|c|}{ Total protein } & \multicolumn{2}{c}{ Crude fibre } \\
\cline { 2 - 5 } & Mean \pm SE & $\begin{array}{c}+,- \\
{[\%]}\end{array}$ & Mean \pm SE & $\begin{array}{c}+,- \\
{[\%]}\end{array}$ \\
\hline Control & $193 \pm 12$ & - & $301 \pm 17$ & - \\
$\mathrm{AF}_{1}$ & $221 \pm 13$ & +14.5 & $280 \pm 16$ & -7.0 \\
$\mathrm{AF}_{2}$ & $191 \pm 11$ & -1.03 & $297 \pm 19$ & -1.3 \\
$\mathrm{AF}_{1,2}$ & $227 \pm 17$ & +17.6 & $278 \pm 18$ & -7.6 \\
\hline $\mathrm{HSD}_{\mathrm{P}=0.05}$ & 21.5 & - & 16.4 & - \\
\hline
\end{tabular}

Mean value \pm standard error (SE),,$+-[\%]$ - increase, decrease to the control, $\mathrm{A}$ - regulator, $\mathrm{F}_{1}$ - sixthleaf stage, $\mathrm{F}_{2}$ - early-bud stage

Additionally, the changes in the content of the above fractions, like in the case of protein and fibre, showed that there was a relationship between the amount of those compounds and the time when the regulator was applied. Acid Detergent Fibre was an exception, with its concentration ranging from 324 to $341 \mathrm{~g} \mathrm{~kg}^{-1} \mathrm{DM}$, without any statistically significant differences between plants of different experimental variants. As regards NDF, ADL, cellulose, and hemicellulose, regulator application resulted in lower content of those compounds in the dry matter of plants treated during the vegetative stage (variants $\mathrm{AF}_{1}$ and $\mathrm{AF}_{1,2}$ ).

One of the characteristics of hormones is their interaction with other hormones, an example of which is exogenous cytokinin and auxin, in particular in high doses, stimulating ethylene biosynthesis in plant tissue (Lorteau et al., 2001; Khan et al., 2002). Due to the effect of cytokinin and auxin application, different responses of plants treated may be an effect of a greater ethylene concentration, not a reaction to those hormones themselves. Some of such responses may be earlier flowering and fruiting in some plants (Pandey et al., 2003). Another example is an interaction of cytokinin with auxin in stimulating cambium growth and in the forming of vascular tissue, which results in a better transport of photosynthesis products and, in consequence, in a higher yield (Aldesuquy, 2000). In the past synthetic hormones were used for flower thinning to regulate the fruit number. By dropping off some buds and flowers, the plant regulates the number of fruit (Bangerth, 1989).

However, it happens that too many buds or flowers fall off and then the number of fruits is smaller and so is the yield. Some plants, including soya, bloom profusely but young flowers and pods, contrary to fully grown and ripe fruits, drop off in a considerable number (Cho et al., 2002). As a result, the production potential of such plants is smaller (Rylott and Smith, 1990). Generally, there are differences between plants when it comes to the process of flowering, and those differences are also caused by different hormone activity (Galoch et al., 1996). There is relationship between the amount of endogenous cytokinin and the number of fallen flowers and pods from soybean plants (Noden et al., 1990). According to another study, treating plants with synthetic cytokinin prevents this process, balancing hormone level and activity (Nagel et al., 2001). Some researchers have found that auxin is especially important, in 
particular in legumes, with their yield potential not fully achieved despite the fact that those plants can produce large quantities of organic matter (Reinecke et al., 1999). In the Polish climate soybean is one of plants in which the level of auxin in young flowers is too low, which again may be the cause of flowers and pods falling off, resulting in lower yield. Auxin application may change this process if only because there are some enzymes in plants decomposing natural auxin relatively quickly (Rylott and Smith, 1990).

Table 9. The effect of growth regulator applied at different times on concentration of cell wall fibre fractions: $N D F, A D F, A D L$, cellulose and hemicellulose $\left[\mathrm{g} \mathrm{kg}^{-1} \mathrm{DM}\right]$

\begin{tabular}{|c|c|c|c|c|c|c|c|c|c|c|}
\hline \multirow{2}{*}{ Variants } & \multicolumn{2}{|c|}{$\begin{array}{c}\text { NDF - Neutral } \\
\text { Detergent Fibre }\end{array}$} & \multicolumn{2}{|c|}{$\begin{array}{c}\text { ADF - Acid } \\
\text { Detergent Fibre }\end{array}$} & \multicolumn{2}{|c|}{$\begin{array}{c}\text { ADL - Acid } \\
\text { Detergent Lignin }\end{array}$} & \multicolumn{2}{|c|}{ Cellulose } & \multicolumn{2}{|c|}{ Hemicellulose } \\
\hline & $\begin{array}{c}\text { Mean } \pm \\
\text { SE }\end{array}$ & $\begin{array}{l}+,- \\
{[\%]}\end{array}$ & Mean \pm SE & $\begin{array}{l}+,- \\
{[\%]}\end{array}$ & $\operatorname{Mean} \pm \mathbf{S E}$ & $\begin{array}{l}+,- \\
{[\%]}\end{array}$ & $\begin{array}{c}\text { Mean } \pm \\
\text { SE }\end{array}$ & $\begin{array}{l}+,- \\
{[\%]}\end{array}$ & $\begin{array}{c}\operatorname{Mean} \pm \\
\text { SE }\end{array}$ & $\begin{array}{l}+,- \\
{[\%]}\end{array}$ \\
\hline Control & $539 \pm 21$ & - & $1+11$ & - & & - & & - & & - \\
\hline $\mathrm{AF}_{1}$ & & -9. & $329 \pm 17$ & -1.5 & $40.3 \pm 7.8$ & -20.7 & $249 \pm 16$ & -13.5 & \pm 13 & -13.4 \\
\hline $\mathrm{AF}_{2}$ & $528 \pm 17$ & -2 . & $324 \pm 18$ & -3.0 & & -3.8 & $284 \pm 15$ & -1.4 & $208 \pm 19$ & -4.1 \\
\hline $\mathrm{AF}_{1,2}$ & $471 \pm 18$ & -12.6 & $341 \pm 16$ & +2.1 & $41.7 \pm 6.7$ & -21.0 & $259 \pm 17$ & -10.1 & $191 \pm 13$ & -12.8 \\
\hline $\mathrm{ISD}_{\mathrm{P}=0.05}$ & 37.2 & - & n.s. & - & 9.8 & - & 27.6 & - & 19.3 & - \\
\hline
\end{tabular}

Mean value \pm standard error $(\mathrm{SE}),+,-[\%]-$ increase, decrease to the control, $\mathrm{A}$ - regulator, $\mathrm{F}_{1}$ - sixthleaf stage, $\mathrm{F}_{2}$ - early-bud stage, n.s. - not significant

The seed yield depends on pod formation and, to a large extend, on the amount of photosynthetic products and other nutrients transported to pods. Plant hormones, like auxin and cytokinin, take part in distribution of photosynthetic products, stimulating their transport and storage (Rodrigo et al., 1997). Hormones also take part in regulating transport and distribution of nutrients by affecting growth of recipient sink sells and the activity of enzymes dealing with phloem loading and unloading, but they also function as signal substances indicating that sink cells need to be filled with photo assimilates. Plant hormones affect flower stalk thickening by regulating vascular tissue development, at the same time making transport of photo assimilates from vegetative to generative parts more efficient, which, in turn, increases seed yield (Nagel et al., 2001; Aldesuquy, 2000).

Hormones, apart from regulating transport of nutrients, also affect their uptake by plants and their remobilisation during seed formation, at the same time influencing the yield (Czapla et al., 2005). The growth of aboveground mass and of mineral content in plants as a result of regulator application is in fact an effect of a bigger growth of the root system, in particular the lengthening of the root hair zone (Bertell and Eliasson, 1992; Metwally et al., 1997). In consequence, the absorption of water and dissolved mineral nutrients is more intensive. Auxin is the most important factor in this process because it sends out a signal about the demand of sink sells for nutrients and about their state (Haiser and Jönsson, 2006).

Rylott and Smith (1990) found that in plants treated with synthetic auxin, there may be a growing dominance of generative parts over vegetative parts. It was also confirmed by the research of Pandey et al. (2003), who treated cotton plants with IAA and found increased flower sizes. In turn Nagel et al. (2001) discovered that synthetic cytokinin stimulates vascular tissue development and improves transport of bio assimilates from 
vegetative to generative parts, increasing their content in conducting tissue of plants. Finally, Barcley and McDavid (1998) found that pigeon pea plants developed much bigger pods with bigger mass if they were treated with 6-benzylaminopurine (BAP).

Recently there has been a growing interest in foliar treatment with mineral growth regulators in the form of titanium chelate. It has turned out that this chemical compound increases chlorophyll content in leaves, improves immunity to fungal and bacterial diseases, fosters development and growth of leaves, increasing plant yield (Pais, 1993; Prusiński and Kaszkowiak, 2005). Titanium chelate is predominantly used in growing vegetables. Cucumber plants treated three times with a $0.02 \%$ solution of this chelate had up to $100 \%$ more seeds. Dressing pea seeds with titanium chelate increased the number of pods and resulted in a $60 \%$ growth in their yield. In an experiment with bean plants the weight of seeds was also higher but the yield increased by several percent only (Nalborczyk, 1993).

In an experiment carried out by Prusiński and Kaszkowiak (2005) on the effect of titanium in a form of Tytanit, a foliar fertilizer, on yellow lupine, there was a significant increase of the yield, by $7.4-18 \%$. In fact titanium did not significantly increase the seed yield from the main stem, but its application resulted in a significant rise in the number of pods and seeds from branches. However, protein content and its structure in seeds were more affected by the hydro-thermal conditions than by the application of titanium. Similarly, titanium did not affect seed thickness, which was closely related to growth conditions rather than titanium application. Even if titanium affects the activity of photosynthesis (Pais, 1993), decreasing symbiosis efficiency after plant blossom fall (Ruszkowska, 1991), its effect on the supply of assimilates to seeds is still too low to diversify seed plumpness. However, a better formation of seeds in the pods on the main stem and a significantly higher yield of seeds from branches show a substantial role of titanium in the processes of photosynthesis and accumulation. A double application of a $0.02-0.04 \%$ solution of titanium straight after plant blossom fall and 7-10 days later resulted in the highest lupine yield (Prusiński and Kaszkowiak, 2005). Titanium applied to legume plants increases intensity of photosynthesis and the mass of the aboveground parts. As a result of an experiment on the effect of titanium application on tomato plants grown on rockwool it was found that the application of titanium at an annual dose of $960 \mathrm{~g} \mathrm{Ti} \cdot \mathrm{ha}^{-1}$ significantly increased total and marketable yields (Kleiber and Markiewicz, 2013). Plant nutrition with titanium resulted in a significant increase in the yield of fruit with the greatest diameters in comparison with other tested combinations. Titanium application positively affected the content of the following nutrients: nitrogen, phosphorus, calcium, magnesium, and potassium.

\section{Conclusion}

1. Treating Medicago x varia T. Martyn plants with a mixture of synthetic growth hormones and titanium chelate increased the breadth of stomata and the length of the stomatal pore. The same treatment affected the length of plant shoots, the number of shoots, but also the mass of shoots, flowers, and roots. In consequence, the total mass of plants was higher.

2. There was a change in plant phytochemistry, with an increase in the content of protein, phosphorus, potassium, manganese, and titanium in aboveground parts. What is more, plants treated with this substance had a lower 
concentration of crude fibre, NDF and ADL fractions, cellulose, and hemicellulose.

3. Furthermore, it should be noted that the best results were achieved after the plants were treated in the vegetative period, during the six-true-leaf stage (variant $\mathrm{AF}_{1}$ ) and when the plants were treated twice (variant $\mathrm{AF}_{1,2}$ ).

Acknowledgements. The research carried out under the theme No 357/13/S was financed by the science grant of the Ministry of Science and Higher Education.

\section{REFERENCES}

[1] Aldesuquy, H. S. (2000): Effect of indol-3-yl acetic acid on photosynthetic characteristics of wheat flag leaf during grain filling. - Photosynt. 38(1): 135-141.

[2] Bangerth, F. (1989): Dominance among fruits/sinks and the search for a correlative signal. - Physiol. Plant 76: 608-614.

[3] Barcley, G. F., McDavid, C. R. (1998): Effect of benzylaminopurine on fruit set and seed development in pigeonpea (Cajanus cajan). - Sci. Hort. 72: 81-86.

[4] Bertell, G., Eliasson, L. (1992): Cytokinin effect on root growth and possible interactions with etylene and indole-3-acetic acid. - Physiol Plant 84: 255-261.

[5] Carvajal, M., Alcaraz, C. F. (1998): Why is titanium a beneficial element for plants? - J. Plant Nutr. 21(4): 655-64. doi:dx.doi.org/10.1080/ 01904169809365433.

[6] Cho, T., Suh, K. S., Park, H. K., Wodd, A. (2002): Impact of 2,4-DP and BAP upon pod set and seed yield in soybean treated at reproductive stages. - Pl. Growth Regul. 36: 215-221.

[7] Czapla, J., Stasiulewicz, L., Nogalska, A. (2005): Spring triticale yield as dependent upon growth regulators, applied alone or in combinations with magnesium sulphate. - Acta. Sci. Pol., Agricultura 4(2): 29-36.

[8] Dodd, C. (2003): Hormonal Interactions and Stomatal Resonses. - J. Plant Growth Regul. 22: 32-46.

[9] Galoch, E., Burkacka-Łakajtus, E., Kopcewicz, J. (1996): Effect of cytokinins on flower differentiation in cultured plants of Pharbitis nil Chois. - Acta Physiol. Plant 18(3): 223-227.

[10] Gupta, S., Gupta, N. K., Kumar, A. (1999): Effect of abscisic acid (ABA) and kinetin (Kn) on water loss from cowpea (Vigna unguiculata L.) seedlings. - Ann. Biol. 15: 77-79.

[11] Haiser, M. G., Jönsson, H. (2006): Modeling auxin transport and plant development. - J. Pl. Growth Regul. 25: 302-312.

[12] Khan, N. A., Khan, M., Ansari, H. R. (2002): Auxin and defoliaton effects on photosynthesis and ethylene evolution in mustard. - Sci. Hort. 96: 43-51.

[13] Klamkowski, K., Treder, W., Marasek, A., Borkowska, B. (2008): Characteristics of stomata and gas exchanges of strawberry plants, depending on growth conditions. - Adv. Agric. Sci Problem Iss. 524: 499-509.

[14] Kleiber, T., Markiewicz, B. (2013): Application of "Tytanit" in greenhouse tomato growing. - Acta Sci. Pol. Hortorum Cultus 12(3): 117-126.

[15] Kocira, A., Świeca, M., Kocira, S., Złotek, U., Jakubczyk, A. (2016): Enhancement of yield, nutritional and nutraceutical properties of two common bean cultivars following the application of seaweed extract (Ecklonia maxima). - Saudi J. Biol. Sci. 25: 563-571. http://dx.doi.org/10.1016/j. sjbs.2016.01.039.

[16] Lorteau, M. A., Ferguson, B. J., Guinel, F. C. (2001): Effect of cytokinin on ethylene production and nodulation in pea (Pisum sativum) cv. Sparkle. - Physiol. Plant. 112: 421-428.

[17] Metwally, A., Tsonev, T., Zeinalov, Y. (1997): Effect of cytokinins on the photosynthetic apparatus in water-stressed and rehydrated bean plants. - Photosynt. 34: 563-567.

[18] Nagel, L., Brewster, R., Riedell, W. E., Reese, R. N. (2001): Cytokinin regulation of flower and pod set soybeans (Glycine max L. Merr.). - Ann. Bot. 88: 27-31. 
[19] Nalborczyk, E. (1993): Biological conditions of legumes productivity. - Fragm. Agron. 4: 147-150.

[20] Noden, L. D., Santokh, S., Letham, D. S. (1990): Correlation of xylem sap cytokinin levels with monocarpic senescence in soybean. - Pl. Physiol 93: 33-39.

[21] Pais, I. (1993): The biological importance of titanium. - J. Plant Nutr. 6: 3-131.

[22] Pandey, D. M., Goswami, C. L., Kumar, B. (2003): Physological effects of plant hormones in cotton under drought. - Biol. Plant 47(4): 535-540.

[23] Pospišilová, J. (2003): Interaction of cytokinins and abscisic acid during regulation of stomatal opening in bean leaves. - Photosynt. 41(1): 49-56.

[24] Prusiński, J., Kaszkowiak, E. (2005): Effect of titanium on yellow lupin yielding (Lupinus luteus L.) - EJPAU 8(2): \#36.

[25] Reinecke, D. M., Ozga, J. A., Ilić, N., Magnus, V., Kojić-Prodić, B. (1999): Molecular properties of 4-substituted indole-3-acetic acids affecting pea perocarp elongation. - Pl. Growth Regul. 27: 39-48.

[26] Rodrigo, M. J., Garcia-Martinez, J., Santes, C. M., Gaskin, P., Hedden, P. (1997): The role of gibberellins A1 and A3 in fruit growth of Pisum sativum L. and the identification of gibberellins A4 and A7 in young seeds. - Planta 201: 446-455.

[27] Ruclová, J., Pospišilová, J. (2001): Effect of benzyloaminopurine on rehydration of bean plants after water stress. - Biol. Plant 44: 75-81.

[28] Ruszkowska, M. (1991): Role of Microelements in the Biological Fixation of Nitrogen. Mat. VI Symp. Mikroelementy w rolnictwie, pp. 5-13. - AR, Wrocław.

[29] Rylott, P. D., Smith, M. L. (1990): Effects of applied growth substances on pod set in broad beans (Vicia faba var. major). - J. Agri. Sci. 114: 41-47.

[30] Saibo, N. J. M., Vriezen, W. H., Beemster, G. T. S., Van Der Straeten, D. (2003): Growth and stomata development of Arabidopsis hypocotyls are controlled by gibberellins and modulated by etylene and auxins. - Plant J. 33: 989-1000.

[31] Scacchi, E., Osmont, K. S., Beuchat, J., Salinas, P., Navarrete-Gomez, M., Trigueros, M., Ferrandiz, C., Hardtke, C. S. (2009): Dynamic auxin-responsive plasma membrane-tonucleus movement of Arabidopsis BRX. - Development 136(12): 2059-2067. http://dx.doi. org/10.1242/dev.035444.

[32] Schroeder, J. I., Allen, G. J., Hugouvieux, V., Kwak, J. M., Waner, D. (2001): Guard cell signal transduction. - Annu. Rev. Plant Physiol. Plant Mol. Biol. 52: 627-658.

[33] Sosnowski, J, Malinowska, E., Jankowski, K., Redzik, P. (2016a): Morpho-chemical diversity in Festuca pratensis and Lolium perenne depending on concetrations of Eclonia maxima extract. - Appl. Ecol. Env. Res. 14(3): 369-379. http://dx.doi.org/10.15666/aeer/1403_369379.

[34] Sosnowski, J., Jankowski, K., Malinowska, E., Król, J., Redzik, P. (2016b): The effects of exogenous plant growth regulator on morphological characteristics alfalfa (Medicago $x$ varia T. Martyn). - Appl. Ecol. Env. Res. 14(4): 421-428. http://dx.doi.org/10.15666/aeer/1404_421428.

[35] Sosnowski, J., Jankowski, K., Malinowska, E., Truba, M. (2017a): The effect of Ecklonia maxima extract on Medicago x Varia T. Martyn biomass. - J. Soil Sci. Plant Nut. 17(3): 770-780.

[36] Sosnowski, J., Malinowska, E., Jankowski, K., Król, J., Redzik, P. (2017b): An estimation of the effects of synthetic auxin and cytokinin and the time of their application on some morphological and physiological characteristics of Medicago x varia T. Martyn. - Saudi J. Biol. Sci. https://doi.org/10.1016/j.sjbs.2016.12.023. 